\title{
Measurements of $17 \beta$-estradiol levels in mice for migraine research
}

\author{
K Chan ${ }^{1 *}$, S Labruijere ${ }^{1}$, I Garrelds ${ }^{1}$, A Danser ${ }^{1}$, C Villalón², A MaassenVanDenBrink ${ }^{1}$ \\ From The European Headache and Migraine Trust International Congress \\ London, UK. 20-23 September 2012
}

\section{Introduction}

Since migraine prevalence is $2-3$ times higher in women than in men, especially during the reproductive years, fluctuations in female sex hormone levels seem to be one of the key factors involved in the pathogenesis of migraine. During the last decade, lots of animal research in migraine has been performed on mice, since this species is well suited to create transgenic animal models1. To investigate the effect of female sex hormones in a murine model, it is important to analyse the hormone levels and/or to determine the hormone cycle in mice. Although no reliable assay has been available to measure murine plasma estrogen, recently $17 \beta$-estradiol assays have been suggested to be able to quantify these hormone levels.

\section{Purpose}

We set up a pilot study to test 3 different ELISA kits described in the literature.

\section{Methods}

Plasma samples and vaginal smears of female mice (10-11 weeks) were collected at two different time points: 3 days before and 2 weeks after ovariectomy (OVX), when the animals were sacrificed. Weights of uterus were also collected. Blood samples were tested in 3 different ELISA kits obtained from Cayman Chemical (Ann Arbor, MI, USA), GenWay Biotech (San Diego, CA, USA) and Calbiotech (Spring Valley, CA, USA), respectively.

\section{Results}

All the tested ELISA assays did not show any differences in $17 \beta$-estradiol levels before and after OVX. Likewise, no differences in $17 ß$-estradiol levels between shamoperated and OVX animals were observed using these

${ }^{1}$ Erasmus Medical Center, Netherlands

Full list of author information is available at the end of the article assays. Data from vaginal smears and uterus weights (sham: 42.7-94.8 mg, OVX: 16.2-52.0 mg), however, confirm that OVX was successfully performed.

\section{Conclusion}

We conclude that the tested ELISA assays are not capable of precisely determining $17 \beta$-estradiol levels in mice. Since vaginal smears, uterus weights and ovary staining are indicative of the phase of the cycle, in future studies these parameters may be used to analyze the hormonal status in mice.

\section{Author details}

${ }^{1}$ Erasmus Medical Center, Netherlands. ${ }^{2}$ Cinvestav Coapa, Czda, Mexico.

Published: 21 February 2013

\section{Reference}

1. van den Maagdenberg AMJM, Haan J, Terwindt GM, Ferrari MD: Migraine: Gene mutations and functional consequences. Curr Opin Neurol 2007, 20(3):299-305.

doi:10.1186/1129-2377-14-S1-P92

Cite this article as: Chan et al:: Measurements of $17 \beta$-estradiol levels in mice for migraine research. The Journal of Headache and Pain 2013 14(Suppl 1):P92.

Submit your manuscript to a SpringerOpen ${ }^{\bullet}$ journal and benefit from:

- Convenient online submission

- Rigorous peer review

- Immediate publication on acceptance

- Open access: articles freely available online

$\rightarrow$ High visibility within the field

Retaining the copyright to your article

Submit your next manuscript at $>$ springeropen.com c) 2013 Chan et al; licensee Springer. This is an Open Access article distributed under the terms of the Creative Commons Attribution License (http://creativecommons.org/licenses/by/2.0), which permits unrestricted use, distribution, and reproduction in any medium, provided the original work is properly cited. 